\title{
Slovenska glasba med evropskim in izvirnim*
}

\section{Slovenian Music between the European and the Original}

Ključne besede: slovenska glasba, evropska glasba, glasbena obdobja, bibliografija.

POVZETEK

Ker se je slovenska glasba v vseh obdobjih od srednjega veka do danes razvijala vzporedno z zahodnoevropsko, se postavlja vprašanje historičnega razmerja: kaj je od te glasbe sprejemala in kaj ji je po svojih močeh, s svojimi predstavniki in ustanovami, prispevala. Namen besedila je predstaviti slovensko glasbo $v$ njeni zgodovinski nacionalni (in $\mathrm{s}$ tem tudi prednacionalni) vlogi in jo obenem identificirati $v$ vlogi izvirnega preseganja na evropsko
Keywords: Slovenian music, European music, musical periods, bibliography

SUMMARY

Through all periods, from the Middle Ages to this day, Slovenian music has been developing parallel with that of Western Europe. Hence, there arises the question of historical relations: what has it received from, and what has it - to the best of its abilities, and through its representatives and institutions - contributed to this music. The aim of the text is to introduce Slovenian music in its historically national (and therefore also prenational) role, and after its originality seems to have exceeded expectations, in its ascension to European or, more directly, Central European standards - individually, creatively, interpretationally, and institutionally.

Razmerje, kakor je zajeto v naslovu tega besedila, seveda ne želi odrekati temu, kar je evropsko, bodisi ustvarjalno ali poustvarjalno, izvirnosti. Nasprotno, gre vendar za najvišjo obliko izvirnosti. Prav tako ne želi pripisovati nacionalnemu in z njim prednacionalnemu absolutne izvirnosti, ker je to nastajalo v kontekstu evropskega duha časa. Pa tudi evropsko izvirnost je treba najprej razumeti kot izvirnost posameznih evropskih področij, pokrajin, mest, dvorov, cerkva itd., poznejših narodnih

* Besedilo je bilo predstavljeno na simpoziju Die Grundlagen der slowenischen Kultur, ki ga je od 4. do 8. septembra 2002 v Göttingenu priredila nemška akademija znanosti in nanj povabila Slovensko akademijo znanosti in umetnosti. 


\section{MUŻKOLOŠKI ZBORNIK • MUSICOLOGICAL ANNUAL XXXIX}

skupnosti, ki je prav tako nastajala v evropskem kontekstu in je bila splošno sprejeta, včasih pa tudi pozneje odkrita in zato lahko brez vzvratnega vpliva. Izvorno je bila vsa ta izvirnost izvirnost posameznikov. Bila je torej individualni prispevek vseprežemajočega evropskega duha, izvirnega duha časa in njegovih sprememb kot sprememb vrednot, ki je individualno oblikoval tudi evropske umetnosti. Glede na to in točneje povedano izpričuje evropska glasbena umetnost izvirnost tako v individualnem umetniškem kot v razvojnem smislu, dveh vidikih enega in istega dejstva. To je tista glasba, ki je ohranila nacionalno oziroma prednacionalno identiteto, iz katere je praviloma izšla, in je obenem segla prek nacionalnih meja na evropsko raven. Pomembna je bila torej za individualne dosežke in razvojni potek evropske glasbene kulture, zmožna je bila nagovoriti tudi evropskega človeka.

Nacionalna izvirnost, v katero terminološko uvrščamo tudi dolgo in vsekakor daljšo prednacionalno fazo razvoja, torej lahko pomeni obenem evropsko izvirnost, ki nas tu zanima, ne pa seveda nujno. To velja za vse nacionalne prispevke evropskih narodov, tudi za slovenskega, ki ga želimo predstaviti v njegovi temeljni nacionalni vlogi in obenem identificirati $v$ vlogi izvirnega preseganja na evropsko ali neposredneje srednjeevropsko individualno ustvarjalno, poustvarjalno ali institucionalno raven.

Tako postavljeno razmerje med evropskim kot temeljno orientacijskim in vplivnim in po drugi strani izvirnim kot nacionalno presegajočim predpostavlja, da se je slovenska glasba razvijala v skladu z zahodnoevropsko. To pomeni, da je pripadala njenemu civilizacijskemu in kulturnem območju, kar se v institucionalnem državnem smislu potrjuje šest stoletij znotraj slovenske zgodnjesrednjeveške države Karantanije (ok.570-12. stoletje) in zatem šest stoletij znotraj habsburške monarhije do njenega razpada. Pri tem ne upoštevamo spoznanj venetskih raziskav, aktualnih nekako zadnji dve desetletji in njihovih predhodnikov, po katerih so bili slovenski predniki Veneti med vzhodnimi Alpami, Panonsko nižino in Jadranskim morjem staroselci z blizu tri tisoč let staro kulturo. Po še ne dokončanih raziskavah te teorije o slovenskem izvoru, temelječi na nekaj virih, so bili Veneti kot pripadniki širše zahodnoslovanske skupine osrednji oblikovalci predrimske srednjeevropske kulture, ki je bila temelj evropski poantični kulturi, kar kaže na daljnosežno prevrednotenje evropske zgodovine. ${ }^{1}$ Vendar o njej ni glasbeno oprijemljivih dejstev, kot jih ni sprva za Karantanijo, pri kateri se venetska naziranja o avtohtonosti in uradna zgodovina o preseljevanju narodov stikata. Po tej drugi, temelječi na sklepanju, so priseljeni zahodni Slovani s severa in južni z jugovzhoda utemeljili Karantanijo kot prvo slovensko in slovansko državo. Ta je s svojo državnostjo - državnim pravom institutio Sclaveni$c a,{ }^{2}$ demokracijo - ustoličevanje koroških vojvod, in knjižnim jezikom in kulturo, kot jo izpričujejo Brižinski spomeniki (najverjetneje okoli 970 po predlogah iz 8. ali začetka 9. stoletja), ${ }^{3}$ bistveno prispevala k srednjeevropski identiteti. Karantansko kraljestvo,

1 Tomažič 1990, še zlasti poglavje Stara zgodovinska pričevanja, 55-57, in kritičen pretres uradne teorije v poglavju Teorija o prihodu Slovencev v 6. stoletju, 123-129.

2 Šavli 1990.

3 Kot Freisinger Denkmäler jih hrani državna knjižnica v Münchnu. Prim. Ramovš \& Kos 1936, Zbornik Brižinski spomeniki 1996. 
pozneje Velika Karantanija, je okoli leta 1000 kot Velika vojvodina Karantanija zajemala domala vse slovensko etnično ozemlje, vključujoč še Furlansko, Veronsko in Istrsko krajino. Sprva samostojna Karantanija je po napadu Avarov 745, ko so Karantanci skupaj z Bavarci premagali napadalce, priznala frankovsko nadoblast, ob tem zadržala svojo državnost in postala v začetku 9. stoletja del Svetega rimskega cesarstva. To je bilo ključno zgodovinsko dejanje, ki je pomenilo s sprejetjem razvitejše oblike fevdalizma sprejem krščanske vere in potrditev pripadnosti zahodnoevropski civilizaciji in kulturi.

Zato velja tudi v glasbeni kulturi za mejnik obdobje pokristjanjevanja od okoli 745 do 10. stoletja, o čemer priča rokopis Conversio Bagoariorum et Carantanorum iz $871{ }^{4}$ Kot v zahodnoevropski in s tem v srednjeevropski srednjeveški umetnosti je temeljilo predvsem na gojenju vokalne glasbe $\mathrm{v}$ cerkvah in samostanih. Ko so si slovenski predniki Karantanci 753 pri Krnskem gradu postavili prvo stolnico, cerkev Gospe Svete, se je umetna glasba postopno širila kot petje gregorijanskega korala in se $v$ poznem srednjem veku razvila $v$ gojenje figuralnega večglasja. ${ }^{5} \mathrm{O}$ teh začetkih pričajo ohranjeni kodeksi in številni fragmenti, nastali od 10. stoletja, za katere domnevamo, da so bili predvsem prinešeni iz zahoda in severa Evrope in veljajo za njen neposredni vpliv. ${ }^{6}$ Pomembno vlogo ob tem je imelo ljudsko petje, od 8 . stoletja znano kot petje kirielejsonov, o katerem priča Conversio in pri njem izrecno o rabi slovenskega jezika Brižinski spomeniki. Od 11. stoletja in v novih okvirih še v 15. stoletju je dokumentirano petje slovenskega kirielejsona ob ustoličevanju karantanskih oziroma koroških vojvod, obreda kakor drugje kronanja, ki je že od 15. in 16. stoletja vzbujal veliko pozornosti zaradi svoje enkratne oblike državne demokratičnosti. ${ }^{7}$ Ta karantanska izvirnost na glasbenem področju, ki se je oplajala z gregorijanskim koralom, je bila podobno relativna pri širjenju srednjeveške slovenske cerkvene pesmi, katere nekaj primerkov so nam v 16. stoletju ohranili slovenski protestanti v izdajah svojih pesmaric. Enoglasne pesmi so namreč krožile v širšem srednjeevropskem prostoru in ljudstvo jih je prevzemalo $\mathrm{v}$ prevodih in priredbah latinskih in še posredno nemških predlog v slovenščino.

Iz vizitacijskih zapisnikov Paola Santonina, tajnika kardinala in oglejskega patriarha Marca Barba, ki je med leti 1485 in 1487 spremljal škofa Pietra Carla na poti po Koroškem, Kranjskem in Štajerskem, imamo potrdila, da je bilo v poznem srednjem veku na Slovenskem razvito večglasno figuralno petje. Isti pisec potrjuje tudi gojenje posvetne in posebej inštrumentalne glasbe, o čemer sklepamo tudi iz številnih fresk. ${ }^{8}$ Posebej razširjena je bila umetna glasba meščanskemu sloju namenjenih vagantov in

\footnotetext{
4 Prim. Kos 1936.

5 Med splošnimi glasbenozgodovinskimi in drugimi deli, ki jih tu navajamo tudi za poznejša obdobja slovenske glasbe, prim. Cvetko 1958-1960, Cvetko 1967, Cvetko 1975, Cvetko 1991 (2), Klemenčič 2002, Klemenčič 1998 (2), Klemenčič 2001, Höfler \& Klemenčič 1967, Monumenta artis musicae Sloveniae 1983- , Muzikološki zbornik 1965-, Rijavec 1979, Zbornik ob jubileju Jožeta Sivca 2000, Muzikološke razprave 1993 in kot splošni deli tudi z glasbeno tematiko Slovenski biografski leksikon 1925-1991 in Enciklopedija Slovenije 1987-

${ }^{6}$ K literaturi v prejšnji opombi prim. še Höfler 1965, 164-181, Snoj 1987, Snoj 1997, Srednjeveška glasba na Slovenskem in njene europske vzporednice 1998.

7 Klemenčič 2002, 18.

8 Prim. tudi Kuret 1998, 171-178, in Kuret 1973.
} 
fevdalnim ali cerkvenim dvorom posvečenih minesängerjev. Med temi zadnjimi predvsem gostujočimi ustvarjalci in obenem izvajalci sta obiskala slovenske kraje vitez Ulrich von Liechensteinski v 13. stoletju in v 15. stoletju pesnik Oswald von Wolkensteinski; ta drugi je kot poliglot med desetimi jeziki obvladal tudi slovenskega, ki ga je imenoval windisch, se pravi venetski, s katerim se je v več kot 40 uporabljenih besedah ohranila prva slovenska srednjeveška ljubezenska lirika. Oba sta izpričala, da je bila slovenska ljudska pesem cenjena tudi med plemstvom. Prav tako vemo, da takšna izmenjava in ustvarjanje temeljev umetne glasbe takratne slovenske etnije ni potekalo v srednjem veku samo enosmerno, se pravi iz Evrope. Kar zadeva izvajalce, pevce in inštrumentaliste, smemo $\mathrm{v}$ poznem srednjem veku in $\mathrm{v} 16$. stoletju po nekaj znanih primerih sklepati o slovenski glasbeni emigraciji, ki je resda težje razpoznavna zaradi latiniziranih, germaniziranih ali romaniziranih imen. Med njimi najuglednejše mesto zavzema v Ljubljani rojeni Jurij Slatkonja (1456-1522), dunajski škof in vodja kapele cesarja Maksimilijana I., humanist in najbrž tudi skladatelj enoglasnih napevov. ${ }^{9}$ Pod njegovim vodstvom organizatorja, umetniškega vodja in dirigenta je zaslovela po srednjeevropskih deželah in širše in vplivala na glasbeno ustvarjanje in poustvarjanje takratne renesančne glasbe, kar je bil neposreden prispevek srednjeevropski glasbeni kulturi.

Po izumrtju karantanskih vojvod v 13. stoletju je slovenska etnija postopno prehajala v habsburško državo, ki je okoli 1500 zajela že večino slovenskega etničnega ozemlja. To je pomenilo nadaljevanje slovenskega srednjeevropejstva in ohranjanje slovenske identitete $\mathrm{v}$ tedanjem prednacionalnem pomenu, čeprav sprva $\mathrm{v}$ težkih socialnih razmerah. Zlasti turški vpadi, ki so prihajali večidel kot roparski napadi iz slovanskega Balkana, so življenjsko ogrožali slovensko etnijo predvsem v 15. in 16. stoletju, dasiravno si Turki niso slovenskih ozemelj nikoli pokorili. Socialna kriza se je predvsem v 16. stoletju neposredno izrazila v kmečkih uporih, konec tega stoletja je prišlo še do zaostritve $v$ spopadu reformacije $s$ protireformacijo. Kljub tako zaviralnim dejavnikom se je delovanje $\mathrm{v}$ okvirih katoliške glasbene prakse $\mathrm{v}$ samostanih in cerkvah nadaljevalo. Protestantizem je sicer omejil, a ne povsem, dotok renesančne glasbe neposredno iz zahoda, se pravi iz Italije, in še iz avstrijskega severa. Širilo jo je tudi plemstvo, med njimi izdatno rodbina Khislov, ki naj bi se je priselila na Kranjsko v začetku 16. stoletja iz Bavarske in si blizu Ljubljane sezidala graščino Fužine. Kot ljubiteijem in mecenom jim je bilo v drugi polovici 16. stoletja in še pozneje posvečenih več zbirk tedaj uveljavljenih skladateljev iz Italije in dvora v Gradcu in tudi vse slovenske protestantske pesmarice. ${ }^{10}$ Protestantizem se je začel širiti vzporedno $z$ nemškim od dvajsetih let 16. stoletja in je zlasti močno zaznamoval drugo polovico tega stoletja. ${ }^{11} Z$ večjim nemškim civilizacijskim vplivom je prišlo do pomembnega upoštevanja avtohtonega prebivalstva in njegovega nacionalnega jezika. $V$ tem smislu je kot idejni vodja s sodelavci deloval na Slovenskem Primož Trubar (1508-1596), z vzdevkom Carniolánus, kar je pomenilo kranjski, se pravi iz osrednje slovenske pokrajine

\footnotetext{
${ }^{9}$ Prim. tudi Mantuani 1905, 67-68, 75-77, 84-85, 91-92.

${ }^{10}$ Pokorn 1996, 447-449.

${ }^{11}$ Rijavec 1967.
} 
takratne vojvodine Kranjske, duhovnik in izobražen v petju. Že prva tiskana knjiga v slovenščini, Katekizem iz 1550, je vsebovala tudi pesmi in litanije, zapisane v beli menzuralni notaciji. Prvi izdaji slovenske pesmarice Eni psalmi (1567) so sledile še štiri vedno bolj razširjene. ${ }^{12}$ Enoglasni protestantski koral je podobno kot petje kirielejsonov obvladoval skupni srednjeevropski duh, ki ni poznal delitve na germansko in slovansko in je bil blizu tudi slovenskim vernikom. Viri zanj so bili ob že omenjeni srednjeveški slovenski cerkveni pesmi v prvi vrsti seveda nemški, začenši z Luthrovimi pesmaricami, nadalje latinski in še češki. Slovenski protestantje so iz tujih predlog ustvarili samostojne avtorske pesnitve, medtem ko so enoglasne napeve večidel prevzeli. Ti prvi slovenski glasbeni tiski so prav tako prišli iz širšega področja tiskarn $\mathrm{v}$ Ljubljani, Wittenbergu in zlasti iz Tübingena, kjer je bilo dolgoletno Trubarjevo zatočišče v času izgnanstva. Sad njihovih prizadevanj v drugi polovici obravnavanega stoletja je blizu 50 protestantskih knjig vključno s celotnim slovenskim prevodom biblije iz leta 1584. Ker je bil protestantizem razmeroma kmalu, že na prelomu v 17. stoletje, zatrt, ni mogel dati umetniških rezultatov, kot jih poznamo v nemških deželah vse $\mathrm{v}$ naslednje stoletje $\mathrm{z}$ vrhuncem $\mathrm{v}$ delih Johanna Sebastiana Bacha. Imel pa je velik pomen $v$ nacionalnem smislu začenši s knjižno utemeljitvijo slovenskega jezika, kar je vodilo v povezovanje slovenskega človeka in v postopno izoblikovanje slovenske narodne zavesti.

Med vzgojiteljskim kadrom v ljubljanski protestantski šoli omenjamo v letih 15881592 kantorja Wolfganga Stricciusa (pred 1570-po 1611) iz rodnega Wunstdorfa pri Hannovru, ki mu gre še poseben pomen, ker so se med protestantskimi glasbeniki na Kranjskem ohranila le njegova dela. Posvetilo prve zbirke Neue Teutsche Lieder, natisnjene v Nürnbergu, je datiral leta 1588 v Ljubljani, za drugo zbirko, Der Erste Theil Newer Teutscher Gesänge (Ulssen 1593), domnevamo, da je delno nastajala v Ljubljani. Obe zbirki ne moreta zakriti, da so kljub povezanosti z nemškim severom in tradicijo nanju vplivali dosežki renesančne glasbe vključno $s$ beneško tehniko cori spezzati. $^{13}$

V nasprotni smeri govorimo še naprej o slovenski glasbeni emigraciji, kamor je med izvajalci sodil Matej iz Celja, eden najpomembnejših basistov svojega časa, pevec dunajske dvorne kapele v letih 1567-1580. Vendar to velja tudi za poglavitne slovenske ustvarjalce renesančnega in baročnega obdobja. Tako je deloval najpomembnejši slovenski skladateljJacobus Gallus, z vzdevkom Carníolus, tj. Kranjec, kot pevec in dirigent $\mathrm{v}$ samostanih srednjeevropskega prostora in kot vodja škofovske glasbene kapele v Olomoucu ter kantor cerkve sv. Jana v Pragi; Daniel Lagkhner kot organist pri baronu Losensteinu na Nižjem Avstrijskem, Gabrijel Plavec (Plautzius, Plautz, Blautz, tudi on z vzdevkom Carniolus) je bil ugleden kapelnik na dvoru v Mainzu, znan, da je kot glasbenik sodeloval tudi pri cesarskih kronanjih, Janez Krstnik Dolar je vodil glasbo v jezuitski cerkvi Am Hof na Dunaju. Če ne štejemo

\footnotetext{
${ }_{12}^{12}$ Elze 1884, Čerin 1908, Florjanc \& Škulj 1996.

13 Obe Stricciusovi zbirki sta izšli v znanstvenokritični izdaji serije Monumenta artis musicae Sloveniae 1983- , zv. XXXII, 1997 (zunaj Slovenije to dvojezično serijo zastopa založba Bärenreiter iz Kassla). Njun redaktor Jože Sivec je o Stricciusu objavil tudi monografijo: Sivec 1972.
} 
Slatkonje, začenja vrsto slovenskih skladateljev Jurij Prenner (zač. 16. stoletja-1590), rojen Ljubljančan in prvi z vzdevkom Carniolus delujoč v Pragi in na Dunaju. ${ }^{14}$ Kot renesančni mojster in sloveč ustvarjalec motetov, ki so jih razen enega vse danes znane uvrščali v reprezentativne zbirke tedanjega časa, je presegel pomen nacionalnega skladatelja. To lahko trdimo tudi za njegovega poznejšega sodobnika, v Mariboru rojenega Daniela Lagkhnerja (po 1550-po1607), ki je v svojem motetnem opusu segel v pozno renesanso in že deloma proti zgodnjemu baroku. ${ }^{15}$ Jacobus Gallus (1550-1591), v kratkem življenju avtor številnih maš, motetov in madrigalov, vsega več kot 500 kompozicij, sodi s Palestrino in Lassom med najpomembnejše evropske ustvarjalce renesančne glasbe in v sam vrh njenih poznorenesančnih dosežkov. ${ }^{16} \mathrm{Ni}$ ga mogoče uvrščati ne med konservativne ne med radikalne umetnike, vsekakor sodi med izvirne mojstre evropske glasbe, ki so dali kánon njenemu renesančnemu obdobju.

Nasprotno tem zaznamujejo obdobje poldrugega stoletja baročnih prizadevanj na Slovenskem ugodnejše socialne in družbene razmere: kmečki stan se je konsolidiral, turška nevarnost z Balkana se je bistveno zmanjšala po bitki v Sisku 1593, v kateri je slovenski plemič Andrej Turjaški (Andreas Auersperg) v neenakem boju s precej manjšo vojsko napadalce strahovito porazil, razmeroma hitra uveljavitev protireformacije je presegla versko razdvojenost. Tako ugotavljamo še izrazitejše glasbene vplive neposredno iz Italije kot vodilne v baročnem obdobju, za katero je Evropa kot "njena takratna provinca" desetletje do dve pozneje po svoje oblikovala njene dosežke. ${ }^{17} \mathrm{~V}$ Sloveniji govorimo o približno dvajsetletnem zamiku podobdobij zgodnjega, srednjega in poznega baroka med približno 1600-1650-1700-1760, s čimer je razvojno ohranjala stik $z$ najbolj naprednimi evropskimi prizadevanji. Govorimo tudi širše o duhu baroka, ki se je na Slovenskem še posebno razmahnil v likovni umetnosti in arhitekturi, zlasti sakralni, pri čemer je bila vsaj v tem slogovnem obdobju glasba časovno vodilna.

Nekako prva tri desetletja 17. stoletja označuje z zgodnjebaročno še dotok prej ovirane renesančne glasbe. Pečat temu začetnemu obdobju je dajal ideološki vodja protireformacije knezoškof Tomaž Hren, rojen Ljubljančan, svest si svojega slovenskega porekla in kot Trubar pomena slovenščine, človek evropskega formata, ki je sam skrbel in izbiral novo glasbeno literaturo predvsem iz sosednjih Benetk in še iz Gradca. O tem priča ohranjena zapuščina v Narodni in univerzitetni knjižnici v Ljubljani in seznam muzikalij ljubljanske stolnice Inventarium librorum musicalium iz

\footnotetext{
${ }^{14}$ Za te renesančne skladatelje prim. še Höfler 1978 in za Prennerja Federhofer-Königs 1985, 149-161 ter Monumenta ... 1983-, zv. XXIV, 1994.

${ }_{15}$ Sivec 1982, Monumenta ... 1983- , zv. II, 1983 in 1995, XXXIV, 1998.

${ }^{16}$ Poleg že navedene glasbenozgodovinske literature iz opombe 5 prim. monografska dela Škerjanc 1963, Cvetko 1965, Cvetko 1972, Cvetko 1991 (1), Gallusov zbornik 1991, Gallusovi predgovori in drugi dokumenti 1991, Škulj 1992, Škulj 2000, zbornika dveh simpozijev Jacobus Gallus and his time 1985, Gallus Carniolus in evropska renesansa 1991 in 1992, razpravo Boetticher 1986, 5-13, najnovejšo izdajo vseh Gallusovih del v 20 zvezkih Monumenta ... 1983- med leti 1985-1995 in zvočne posnetke mdr. Gallus 2000, Klemenčič 2002.

${ }^{17}$ Navedek in trditev sta iz monografije Bukofzer, Manfred F., Music in the Baroque Era, London 1948. Za slovensko glasbo prim. Klemenčič 1997, 65-84 in Klemenčič 2002, od koder je ponekod v tej razpravi kratko povzeto besedilo.
} 
$1620 \mathrm{z}$ okoli 300 enotami, kjer so ob mojstrih nizozemske, rimske in beneške šole zastopani zgodnjebaročni italijanski skladatelji. ${ }^{18}$ Sprva, od preloma stoletij, so bile pomembne redne uprizoritve jezuitskega gledališča $\mathrm{z}$ vidnim deležem glasbe, zatem opera s prvimi dokumentiranimi predstavami v petdesetih letih 17. stoletja. Pri tem realna je domneva, da bi že ob samem rojstvu opere, se pravi od začetka tega stoletja, izvedli Caccinijevo Euridice, ki jo dvakrat navaja omenjeni Inventarium. Operne uprizoritve kot redna gostovanja italijanskih in pozneje nemških opernih družb so bolje dokumentirane od štiridesetih let 18 . stoletja. ${ }^{19} \mathrm{~V}$ poustvarjalnem institucionalnem smislu največji dosežek tega obdobja je ustanovitev Academie Philharmonicorum Labacensium v letu 1701, ki je že kakšno desetletje prej neformalno delovala vzporedno s sestrsko znanstveno ustanovo Academio Operosorum. ${ }^{20}$ Kot aristokratsko združenje za gojenje baročne glasbe je postala žarišče ustvarjalnega duha in humanizma svojega časa. Njen temeljni prispevek je bil poustvarjalno namenjen dvigu cerkvene glasbe, a tudi širjenju posvetne. Žal se ni ohranila glasba njenega razmeroma širokega skladateljskega kroga, kot tudi tistega jezuitskega gledališča, za katero sklepamo, da jo je že označevala poznobaročna usmerjenost. Bila je prva takšna slovenska in prva evropska ustanova zunaj romanskega in anglosaškega območja, odprta v Italijo, kjer so se šolali mnogi slovenski plemiči in kjer so morali najti spodbude in modele za njeno zasnovo. Kot markanten začetek institucionaliziranega glasbenega poustvarjanja te vrste na Slovenskem in kot pomemben začetek v nemajhnem delu Evrope je Academia Philharmonicorum presegla samo obdobje in območje, $\mathrm{v}$ katerem je nastala. V kontekstu evropske dvosmernosti je sprejela duha in dosežke najrazvitejše evropske glasbe in jih izvirno oblikovane tej vračala.

To velja predvsem iz neposredno srednjeevropskih izhodišč tudi za skladateljski prispevek v tujini delujočih ustvarjalcev s Kranjske. Časovno gre pomen najprej zgodnjebaročnemu Gabrijelu Plavcu (ok. 1590-1641) z edino ohranjeno zbirko duhovnih skladb Flosculus vernalis (1621), v kateri s krepko izraznostjo tega simboličnega "pomladnega cvetja" že izhaja iz zgodnje monodije in generalnega basa. ${ }^{21}$ Pokrajinski pomen delovanja med Koroško s tedaj "slovenskim" Celovcem/Klagenfurtom in Kranjsko z Ljubljano presega tudi Isaac Posch (ok. 1591-1622/1623), ki velja v svojih inštrumentalnih delih za evropsko pomembnega ustvarjalca variacijske suite. ${ }^{22} \mathrm{Ta}$ lokalni pomen pa je presegel tudi v latinskih motetih, s katerimi je monodični koncert po zgledu Lodovica Viadana uveljavil kot novost na območju severno in vzhodno od Italije. Janez Krstnik Dolar (ok. 1620-1673), ki se je od te zgodnjebaročne

\footnotetext{
${ }^{18}$ Cvetko 1959. Za to obdobje prim. še Höfler 1978, Bedina 1992, 5-9, Kokole 1995, št. 2, 91-102, Glasbeni barok na Slovenskem in evropska glasba 1997.

19 Škerlj 1973, Ludvik 1957.

${ }^{20}$ Prim. monografijo Cvetko 1962 in k temu Thalnitscher 1717, Radics 1877, Klemenčič 1988 (2), nadalje Kokole 1996, Slovenska filharmonija - Academia philharmonicorum 2001. Tristoletnici te ustanove sta bila posvečena mednarodna muzikološka simpozija v Ljubljani, oktobra 2001 v organizaciji Muzikološkega inštituta Znanstvenoraziskovalnega centra Slovenske akademije znanosti in umetnosti, aprila 2002 Slovenski glasbeni dnevi; v pripravi sta simpozijska zbornika.

${ }^{21}$ Monumenta ... 1983-, zv. XXXIII, 1997.

${ }^{22}$ Prim. Bukofzer 1948 (v tukajšnji opombi 17), 113; prim. tudi monografijo o Poschu: Kokole 1999 in izdajo celotnega Poschevega opusa v treh zvezkih v Monumenta ... 1983- , XXX in XXXI, 1996, XXXV, 1998.
} 
glasbe razločno odmaknil v srednjo fazo, velja za srednjeevropsko pomembnega ustvarjalca maš, psalmov, sonat in posvetnih baletov, $s$ tem pa tudi za evropsko relevantnega skladatelja. ${ }^{23}$ Lokalni in danes nacionalni pomen gre $\mathrm{v}$ Kopru delujočima skladateljema, zgodnjebaročnemu Gabriellu Pulitiju (ok. 1575-1641/44), ki je z najboljšim zanimiv za evropsko glasbo, ${ }^{24}$ in lokalnemu mojstru visoke kakovosti Antoniu Tarsii (1643-1722), ki še ni polno vstopil v pozni barok. ${ }^{25} \mathrm{~V}$ Piranu rojeni Tartini, violinist evropskega formata, baročni in že zgodnjeklasicistični ustvarjalec, ima $\mathrm{v}$ rodnem mestu spominsko sobo z glasbenoteoretičnimi spisi, sicer je deloval na italijanskih tleh in sodi $\mathrm{v}$ italijansko glasbeno kulturo.

Nov vzpon glasbene umetnosti proti koncu 18. stoletja je bil že posledica vzpona meščanskega stanu. To je pomnožilo ustvarjalne sile, najprej v razsvetljenskih prizadevanjih nekaj krožkov, med katerimi najpomembnejšega je vodil baron Žiga Zois od osemdesetih let tega stoletja, tudi umetnostni mecen in prevajalec italijanskih arij $\mathrm{v}$ slovenščino. $\mathrm{V}$ jezikovni in literarni družbi tega takrat najbogatejšega Slovenca je vzniknilo spoznanje o Slovencih kot narodni celoti, takrat še razcepljeni na deželne enote. V glasbi se je nov duh s klasicističnim repertoarjem začel uveljavljati z gostovanji opernih družb v ljubljanskem Stanovskem gledališču, tako uglednih impresarijev Pietra in Angela Mingottija, Felixa Bernerja (prvič 1768), Mozartovega libretista Emanuela Schikanedra (prva gostovanja v letih 1779-1782) idr. ${ }^{26}$ Slovenski preporod je spodbudil nastanek prve slovenske opere Belin (1780 ali 1782), katere libretist Janez Damascen Dev se je zgledoval pri Metastasiu, avtor pogrešane in verjetno zgodnjeklasicistične glasbe je bil Jakob Zupan. ${ }^{27}$ Iz idej preporoda je nastala tudi iskriva klasicistična scenska glasba Figaro (ok. 1790) k Linhartovi komediji Ta veseli dan ali Matiček se ženi avtorja Janeza Krstnika Novaka. ${ }^{28} \mathrm{~V}$ pevskih prizorih je skladatelj utemeljil slovenščino v glasbenem gledališču, kot je takrat v svojih opernih vrhuncih Mozart nemščino.

Pobudnim vplivom neposredno $\mathrm{z}$ zahoda so tako sledile nove pobude neposredno s severa. Do stika z razvito Evropo je prišlo tam, kjer se je vzpostavil model evropskega klasicizma in dosegel umetniški vrhunec. V ta okvir dosežkov dunajske klasike se je naravno umestila ljubljanska Filharmonična družba (Philharmonische Gesellschaft). V novih razmerah, ko je delo Academie Philharmonicorum zaradi neaktualnosti zastalo, jo je približno stoletje po njeni predhodnici in vzornici leta 1794 ustanovilo kulturno osveščeno meščanstvo, ki je pritegnilo sprva zadržano plemstvo. Zasnovana je bila v duhu kozmopolitizma, združujoč v slovenskem kulturnem

\footnotetext{
${ }^{23}$ Sprva se je obravnaval kot češki skladatelj, na njegovo slovensko poreklo je opozoril Dragotin Cvetko. Prim. Cvetko 1958-1960, I, 217-218, prvi vir Valvasor 1689, VI, 359, gl. tudi Faganel 1989, Faganel 1993 (1), 43-56, Faganel 1993 (2), 141-151, in Monumenta ... 1983- , zv. IV, 1984 in 1995, XXII, 1992 in 1997, XXIII, 1993 in 1997, XXV, 1994, XXIX, 1996.

${ }^{24}$ Italijanski skladatelj je deloval v Trstu, Labinu in Kopru ter objavljal v Benetkah, zato se obravnava tako v italijanski kot hrvaški in slovenski zgodovini glasbe. Znotraj zbirke Monumenta artis musicae Sloveniae je v pripravi izdaja vseh Pulitijevih del z mednarodnim uredništvom vseh treh zainteresiranih strani. Doslej sta izšla dva zvezka: Monumenta ... 1983- , XL, 2001, in XLII, 2002.

25 Antonio Tarsia, 1643-1722 1993, Höfler 1994, 17-21, Faganel 1994, 35-43.

${ }^{26}$ Gl. opombo 19 in še Sivec 1971, Sivec 1978, 77-91. Med splošnejšo glasbeno literaturo prim. Evropski glasbeni klasicizem in njegov odmev na Slovenskem 1988 in še Cvetko 1957, 200-206, Flotzinger 1988, 13-23.

${ }^{27}$ Sivec 1981, Slovenska opera v evropskem okviru, 1982.

${ }^{28}$ Cvetko 1958, 103-106.
} 
središču glasbene ljubitelje nemške manjšine in slovenske večine. ${ }^{29} \mathrm{Ni}$ bilo naključje, da se je $z$ rednim koncertiranjem orkestra in še zbora usmerila v izvajanje klasicistične glasbe in še zlasti del dunajske klasike. Takšno usmeritev je potrdila tudi z izvolitvijo njenih skladateljskih predstavnikov za častne člane. Ker za Mozarta, ki je umrl tri leta pred ustanovitvijo družbe, to ni bilo več mogoče, je čast pripadla njegovemu sinu z istim imenom ob gostovanju v Ljubljani (1820). Vsekakor pa velja izbor za posebno pogosto izvajanega Haydna (1800) in prav tako za Beethovna (1819), ki sta jima sledila med drugimi še Paganini (1824) in pozneje Brahms. ${ }^{30}$ Ustanova si je skupaj s škofovsko kapelo in Stanovskim gledališčem prizadevala tudi za glasbeno vzgojo, kar omenjamo še posebej zato, ker je na razpisu za učitelja glasbe leta 1816 sodeloval takrat 19-letni Franz Schubert, ki pa mu zaradi nepoznanosti in mladosti usoda ni namenila delovanja v Ljubljani. ${ }^{31}$ Do razmaha Filharmonične družbe je morda presenetljivo prišlo ob centralistični politiki habsburške oblasti na Dunaju, kjer se je osredotočala tudi kultura, kar je zmanjševalo vlogo deželnih središč, med katere je sodila Ljubljana. Glede na to, da se Filharmončna družba ni mogla opreti na zglede v habsburški državi in tudi širše, ker so se podobne ustanove začenši z Dunajem ustanavljale nekoliko pozneje in glede na ambiciozno koncertno prakso, ji gre razviden srednjeevropski in s tem evropski pomen, na slovenskih tleh združen z oblikovanjem koncertne tradicije.

Glasbenoustvarjalno se ob že poznani in še aktualni emigraciji v tem obdobju soočamo s pojavom glasbene imigracije, se pravi delovanjem nekaj vidnih avstrijskih in čeških glasbenikov. Osrednja osebnost zlasti zgodnjega klasicizma iz večidel šestdesetih do osemdesetih let je Jakob Zupan, avtor duhovne glasbe, zasnovane v ljudskem in neposrednem in živem liričnem izrazu, ${ }^{32}$ medtem ko je o štajerskem poznoklasicističnem skladatelju Valentinu Lechnerju malo podatkov. Francesco (Franc) Pollini je kmalu zapustil rodno Ljubljano, prišel na Dunaju v stik z Mozartom in se ustalil v Milanu kot ugleden profesor klavirja in mednarodno poznan skladatelj klavirske ter še operne in duhovne glasbe..$^{33}$ Častni član Filharmonične družbe Matej Babnik je odšel v Budimpešto, Jurij Mihevec (Miheuz, Michaux) je deloval na Dunaju, v Parizu in se ustalil v bližnjem Mennecyju kot popularen skladatelj lahkotnejše glasbe. Tako so zlasti v Ljubljani svoje izvajalske in skladateljske izkušnje prispevali Josef Benedikt Dussík, aktiven še v Pragi, Benetkah in milanski Scali in avtor v kranjski prestolnici nastalih simfonij, skladatelj mašnega opusa Venceslav Wratny, ${ }^{34}$ naturalizirani Čeh Gašpar Mašek in med njimi najpomembnejši Leopold Ferdinand Schwerdt

\footnotetext{
${ }^{29}$ Klemenčič 1988 (2) in zgodovinski deli o tej ustanovi: Keesbacher 1862, Bock 1902.

${ }^{30}$ Haydn je ob izvolitvi ljubljanskim filharmonikom poklonil glasove svoje Misse in tempore belli ("Paukenmesse"), Beethoven jim je 1818 izročil prepis partiture Pastoralne simfonije $\mathrm{z}$ lastnoročnimi dodatki in popravki. Obe deli hrani Narodna in univerzitetna knjižnica v Ljubljani. Beethoven je naslednje leto po izvolitvi za častnega člana Filharmonični družbi poslal pisno zahvalo (njegovo pismo je od l. 1956 v Beethovenhaus v Bonnu). Prim. Klemenčič 1988 (1), 123-134, Klemenčič 2000, 119-130.

${ }^{31}$ Mantuani 1930, 195-201.

32 Pokorn 1990-1991, št. 4-5, 177- 181, Škrjanc 1999. V zbirki Monumenta ... 1983- je izšel prvi od dveh zvezkov s celotnim Zupanovim opusom (XXXVI, 1999), drugi (XXXVIII) je v pripravi.

${ }^{33}$ Klemenčič 1992, 73-91.

${ }^{34} \mathrm{~V}$ izboru so izšle v Monumenta ... 1983- tri njegove maše: zv. XXXVII in XXXIX, 2000, LXI, 2001.
} 
z opusom religioznih in posvetnih del. Tudi iz mednarodnih razgledov so prispevali $\mathrm{k}$ oblikovanju in razvoju nacionalno pomembne klasicistične glasbe na slovenskih tleh zlasti $v$ njeni pozni fazi.

Po sprva vzporednih romantičnih glasbenopoustvarjalnih začetkih od dvajsetih let 19. stoletja je s prelomnim časom marčne revolucije dozorelo novo obdobje, ko je začel slovenski narod kot novo oblikujoči se subjekt zavestno in iz lastnih moči ustvarjati glasbo $\mathrm{z}$ nacionalno identiteto, soustvarjajoč tako enega evropskih modelov nacionalno prebujenega razvoja. V letu marčne revolucije nastali politični program Zedinjene Slovenije in kulturna prizadevanja za oblikovanje nacionalne avtonomije in identitete slovenskega naroda sta glasbi sprva odmerili buditeljsko vlogo. Narodnostno prebujanje in evociranje nacionalnih čustev je narekovalo povezovanje besede $\mathrm{z}$ glasbo, tj. petje $\mathrm{v}$ zboru ali še solistično, in $\mathrm{s}$ tem začasno opustitev visokih umetniških ciljev. Dolgoročno je začenjanje na novo zahtevalo institucionalno ustvarjanje razmer za novo, celovito glasbeno življenje naroda. Od 1848 je dobila glasba pomembno vlogo na kulturnih in političnih družabnih prireditvah bésedah $\mathrm{v}$ organizaciji Slovenskega društva, ki je spodbudilo tudi izdajanje pesmarice Slovenska gerlica. Od šestdesetih let se je glasbeno delovanje nadaljevalo v čitalnicah, ki so nastajale v Ljubljani, Trstu, Mariboru in še v kakšnih 60 krajih na slovenskem etničnem prostoru. Njihove prireditve bésede so bile zametek koncertnega življenja. V obdobju prehoda $\mathrm{v}$ šestdeseta leta so narodnobudniške vrednote zamenjale umetniške in $\mathrm{z}$ njimi estetika glasbenega romantizma $\mathrm{z}$ nacionalno identiteto. Vloga čitalnic je s tem prerasla $v$ potrebo po oblikovanju osrednjih ustanov $\mathrm{v}$ podporo vsestranskega razvoja glasbe. Tako je kot prva in najpomembnejša 1872 nastala ljubljanska Glasbena matica. Nekako po dveh desetletjih je dosegala največje uspehe $z$ nastopi dvestočlanskega zbora v večjih vokalno-inštrumentalnih delih, kar se je 1896 potrdilo s koncertom na Dunaju pod dirigentskim vodstvom Antonína Dvořáka, poznejšega častnega člana Glasbene matice. Iz Dramatičnega društva (1867) nastala slovenska Opera je 1892 začenjala v novo zgrajenem Deželnem gledališču, ki ga je sprva delila z nemškim. Na pobudo Glasbene matice je narodno osveščeno meščanstvo utemeljilo Slovensko filharmonijo (1908-1913), h katere umetniškemu vzponu je pomembno pripomogel mladi češki dirigent Václav Talich.

V tako nastali dvojnosti je vzporedno delo Filharmonične družbe potekalo v razvidni organizaciji nemške manjšine, ki je skrbela za celotno glasbeno življenje še s komornimi koncerti in opero. Vodilo je $\mathrm{v}$ zdravo tekmovalnost, objektivno pa tudi $\mathrm{v}$ nasprotja dveh nacionalnih entitet. Za bogato glasbeno življenje slovenske prestolnice do prve svetovne vojne s sporedi, ki so poudarjali bodisi slovenski in slovanski ali nemški repertoar, je bil zaznaven tudi širši evropski duh. K njemu so poustvarjalno prispevali nekateri pomembni dirigenti, tako Talich, ki je nastopal tudi v slovenskem Deželnem gledališču, kjer je bil redno nastavljen Fritz Reiner (v sezoni 1910-1911); med te evropsko in svetovno pomembne poustvarjalce je prav tako sodil mladi Gustav Mahler, ki je v ljubljanskem Stanovskem gledališču začenjal kariero opernega dirigenta $\mathrm{v}$ sezoni $1881-1882 .{ }^{35} \mathrm{~K}$ novim evropskim razgledom so prispevala gosto-

${ }^{35}$ Cvetko 1969, 74-83, Kuret 2001. 


\section{MUZIKOLOŠKI ZBORNIK • MUSICOLOGICAL ANNUAL XXXIX}

vanja nekaterih najboljših orkestrov z Dunaja, Prage in od drugje, tako 1. 1903 Berlinskega orkestra $z$ dirigentom in skladateljem Richardom Straussom.

Novi čas je pred skladatelje postavil še posebno zahtevno nalogo zavestno ustvariti nacionalni izraz. Če sprva zanj ni bilo izrazitih osebnosti, tudi vsebina kompozicijskih začetkov za prebujanje domoljubnih čustev ni terjala visoke profesionalnosti z razvito kompozicijsko tehniko. Vendar že od začetka ni bil romantični ideal nacionalne glasbe navajanje tematike iz znova odkrite zakladnice ljudske glasbe, marveč razvijanje abstraktnega in težko razberljivega izraza v nacionalnem duhu, tiste narodove usedline, ki se je najbolj nedvoumno izoblikovala v njegovem jeziku. ${ }^{36}$ Možnost citiranja je lahko pozneje obstajala le podrejeno. ${ }^{37}$ Iz teh izhodišč so se proti koncu 19. stoletja razvile tri skladateljske osebnosti, med katerimi je bil muzikalno najprodornejši ter $\mathrm{v}$ najboljšem evropsko prepričljiv Benjamin Ipavec, delujoč sicer kot zdravnik v avstrijskem Gradcu. Slovenskost romantičnega glasbenega izraza je utemeljil kot lirično doživetje, iracionalno stanje torej, ki ga je prežel z močnim in toplim čustvom, resnobnim in eksaktno podanim. Ob nacionalno pomembnem Franu Gerbiču se je tudi naturalizirani Čeh Anton Foerster močno približal slovenskemu izrazu, da je - za lokalizacijo dogajanja tudi z obdelavo slovenske ljudske pesmi - ustvaril slovensko nacionalno opero (Gorenjski slavček). Vsi trije so segli in zgoščali svoj izraz od zgodnje do pozne romantike, na njihovih temeljih so nadaljevali ustvarjalci moderne generacije še do nove romantike, impresionizma in zgodnjega ekspresionizma. S starejšo generacijo jih je združil urednik Gojmir Krek v reviji Novi akordi (1901-1914). ${ }^{38}$ Kot vodilni skladatelj, evropski ustvarjalec samospeva in zbora, ji je pripadal Anton Lajovic, ${ }^{39}$ vanjo so sodili Risto Savin, Emil Adamič, Janko Ravnik, iz najmlajše generacije Marij Kogoj, slogovno pa bi tudi slovenskim staršem v Slovenj Gradcu rojeni mojster evropskega samospeva Hugo Wolf, ki se je razvijal in deloval v avstrijskem kulturnem krogu. Novi nacionalni idiom je poosebljal Lajovic s simboličnim sprejemanjem slovenske in evropske glasbene izobrazbe, na Dunaju še posebej srednjeevropskega ozračja pri Robertu Fuchsu, skladateljskem mentorju tudi njegovim sodobnikom Zemlinskemu, Schrekerju, Wolfu, Mahlerju. Iz širših evropskih razgledov je želel ustvariti slovenski nacionalni izraz, ne z navajanjem ljudske pesmi, če že, v njenem duhu, ali z izazom, ki ga lahko doživimo, občutimo kot slovenskega. ${ }^{40}$ To zadnje smemo trditi še za katerega njegovih romantičnih sodobnikov, denimo Savina, prav tako Fuchsovega učenca, ali Josipa Ipavca, ki se je izpopolnjeval pri Zemlinskem in je svoje samospeve evropske vrednosti uglasbil največ na izvirna Heinejeva besedila. Tako se je slovenska glasba do začetka 20. stoletja razvojno zgoščala in po prelomnem letu marčne revolucije slogovno in z umetniškimi dosežki dosegla evropsko.

$\mathrm{Na}$ tej stopnji je slovenski narod kot razvit evropski narod zapustil habsburško monarhijo. Takrat je problematiko razsvetljene srednjeevropske države, ki je stoletja

\footnotetext{
${ }^{36}$ Klemenčič 1999 (1), 269-270.

${ }^{37}$ Podrobneje o tem gl. Klemenčič 1999 (1).

${ }^{38}$ Urejal jo je na Dunaju, izhajala je v Ljubljani. Prim. tudi Cvetko 1977.

39 Škerjanc 1958, Cvetko 1985.

${ }^{40}$ Prim. Klemenčič 1999 (1), 274 in tam opomba 26.
} 
nudila zaščito manjšim narodnim enotam, ni pa zmogla demokratično rešiti nastalega nacionalnega vprašanja, zamenjal še večji problem nove skupne države pod velikosrbsko hegemonijo in centralizmom. Ker ta hegemonija ni mogla temeljiti na evropski kulturi, ki je Srbija od 14. pa vse do druge polovice 19. stoletja zaradi turške okupacije ni poznala, $z$ njo pa tudi umetne glasbe ne, je bil njen nadomestek združevanje na silo. To je pomenilo nacionalno zatiranje $-z$ idejo troedinega naroda Srbov, Hrvatov in Slovencev - in ekonomsko izkoriščanje. Večstoletno evropsko državnost z visoko kulturo je zamenjala avtoritarna država pravoslavno-turškega tipa, zaostala civilizacija s srbskimi imperialističnimi težnjami v vsem 20. stoletju. S tem kraljevina Jugoslavija kot umetna versajska tvorba ni mogla izpolniti velikih upov, za slovenski narod je pomenila odhod iz Srednje Evrope na Balkan in izdajo ideje panslavizma iz 19. stoletja.

Naravno se je zato ohranila vsebinska vključenost slovenske glasbe v evropsko in z njo aktualni evropski model zgoščanja in prekrivanja slogov začenši s koncem 19. stoletja. V razvojnem pospeševanju na Slovenskem se tako med obema vojnama staro meša z novim in najnovejšim, še močno navzoči romantiki se pridružuje impresionizem, njima nasproti prevratnost ekspresionizma $\mathrm{z}$ avantgardnimi poudarki in $\mathrm{k}$ temu še umirjanje z novo stvarnostjo. Osrednja vloga Glasbene matice ostaja, že prej avtonomna Opera doseže prav zdaj velik razmah in razpon do aktualne sodobnosti, medtem ko nacionalnega orkestra ni mogoče obnoviti, kar pomeni zaradi centraliziranega financiranja $v$ Beogradu zaviranje dvestoletnega izročila simfonične reprodukcije na Slovenskem. Njegovo vlogo prevzame v skromnejših okvirih Orkestralno društvo Glasbene matice in od srede tridesetih let še Ljubljanska filharmonija, poleg občasnih nastopov simfoničnega orkestra ljubljanske radijske postaje. V tem kontekstu simptomatično je, da se Dravska banovina, ki ni vključevala vsega slovenskega etničnega ozemlja, ne more imenovati Slovenija, in prav tako s težavo priborjena akademija znanosti ne more biti "slovenska".

$\mathrm{V}$ nemajhnem ustvarjalnem razponu med tradicijo in modernizmom dajejo po predvojnih začetkih takoj po vojni pečat novega že predstavniki impresionizma. Vzore najdejo v čutnem izrazu srednjeevropskega območja ali impresionistični subjektivizem po svoje in izvirno občutijo. Le deloma so v sozvočju s sicer priznanim francoskim modelom, kot denimo Demetrij Žebre. Prvemu občutju blizu so zlasti Lucijan Marija Škerjanc, ena osrednjih osebnosti obdobja med vojnama, značilno študent Josepha Marxa na Dunaju in Vincenta d'Indyja v Parizu, pa tudi Janko Ravnik, ki začenja študijsko usmerjanje slovenskih skladateljev v Prago, že prej in sprva v tem obdobju Lajovic, prav tako delno Adamič, ki vsi v najboljšem prepričljivo dosegajo evropsko raven. Nov duh in rezko reakcijo na upirajočo se tradicijo romantizma vnašata avantgardni generaciji z Marijem Kogojem v dvajsetih in Slavkom Ostercem v tridesetih letih, utemeljujoč novi modernizem z ekspresionistično estetiko. ${ }^{41}$ Pri Kogoju, učencu Schrekerja in Schönberga na Dunaju, pomeni to nov poduhovljen in

\footnotetext{
${ }^{41}$ Prim. Rijavec 1975, O’Loughlin 2000, Klemenčič 1988 (3), Klemenčič 1986, vol. I, 127-139, Marij Kogoj 1892-1992 1993, Klemenčič 1998 (1), 215-235, Cvetko 1988, Cvetko 1993, Klemenčič 1996 (2), 49-63, Bedina 1981.
} 
disharmonični izraz v zmernejši obliki razširjene tonalnosti z delnim preseganjem $\mathrm{v}$ atonalnost, pri Ostercu, učencu Hábe v Pragi, novo stopnjevanje v atonalnost s prvim prodorom $\mathrm{v}$ dvanajsttonsko tehniko in $\mathrm{z}$ uvajanjem poznorekspresionističnega konstruktivistivizma. Njihova prizadevanja dosežejo najvišji umetniški vzpon v operi Črne maske (praizvedba 1929), s katero Kogoj simbolizira ves slovenski, ne le glasbeni ekspresionizem, in jo kot izviren vsebinski prispevek evropskemu ekspresionizmu postavlja ob bok Bergovemu Wozzecku. Pot v novo poduhovljenost dobi najboljši evropski korelat $\mathrm{z}$ dramsko idejo razvoja glavnega junaka - in s tem evropskega človeka, kot jo je označil skladatelj, "od vsakdanjega človeka v duhovnega" ${ }^{42}$ Intermedialni naravi avantgardnega gibanja dvajsetih let se v tridesetih pridruži internacionalnost, kar pomeni povezanost $s$ praškimi glasbenimi avantgardisti in tudi $s$ SIMC. Osterc je takrat uspel preseči zaprtost pomarčnega razvoja $\mathrm{z}$ izvedbami svojih skladb po evropskih glasbenih središčih, predvsem na festivalih sodobne glasbe. V vmesnem obdobju te ekspresionistične zavzetosti je leta 1929 utemeljil objektivno glasbo nove stvarnosti (Neue Sachlichkeit), ki je bila plod idejnih vplivov neoklasicističnega Stravinskega in neposrednješe orientacije pri Hindemithu. To leto nastalo klasično delo, Suito za orkester, označujeta tako slovenski izraz kot evropska raven.

Nova kompozicijska praksa po marčni revoluciji je v obdobju med vojnama privedla do naravne potrebe po osmislitvi vprašanja nacionalnega glasbenega izraza. Izhodišče polemičnih stališč iz dvajsetih let, ki so dobila epilog v tridesetih, je razumljivo postavil Anton Lajovic kot zastopnik nacionalne smeri. Ideološko izhajajoč iz nacionalnih zaostrovanj iz obdobja pred razpadom avstroogrske monarhije se je že kmalu zavzemal za začasno zaporo pred nemškimi vplivi in predlagal favoriziranje slovanske glasbe, naslon na ljudsko glasbo po ruskem, srbskem in hrvaškem vzoru in še profrancosko usmerjenost. ${ }^{43}$ Njegovo stališče je paradoksno demantirala sama Lajovčeva kompozicijska praksa, ki se je odprla evropskemu duhu; zato mu je njegov oponent Marij Kogoj utemeljeno navajal prav vpliv nemške romantike na njegovo ustvarjanje. Nasprotno je menil umetnostni zgodovinar in muzikolog Stanko Vurnik. Lajovčevi trditvi, da je "vrednostni moment $\mathrm{v}$ kulturnih proizvodih posameznega naroda ... podan ravno $\mathrm{v}$ njihovi narodnostni posebnosti, torej $\mathrm{v}$ čemer se ta narod razlikuje od vseh drugih narodov in ne v tem, v čemer si je on $z$ drugimi narodi enak, ${ }^{44}$ je postavil nasproti občečloveškost. Za svoj internacionalizem je trdil, da vsak narod prispeva $\mathrm{k}$ mednarodni umetnosti le tisto skupno in najboljše; zato pri Beethovnu abstrahiramo njegovo nemštvo in iščemo splošno umetniško sporočilo. ${ }^{45}$ Kogoj je v svojem polemičnem odgovoru Lajovcu z značilnim naslovom Vzajemnost evropskih kulturdemokratično menil, da se mora vsak ustvarjalec sam odločiti, "ali naj bo narodna pesem izhodišče za našo muziko ali le človek sam ..." S to formulacijo je kot ekspresionistično predestinirani ustvarjalec postavil najvišje avtonomnost umetnikove izpovedi, njen izraz: "Treba je priti do golega izraza, se pravi, priti do svoje oseb-

\footnotetext{
${ }^{42}$ Klemenčič 1988 (3), 65.

${ }^{43}$ Klemenčič 1999 (1), 270-271, Klemenčič 1988 (3), 60ss, Umetnik in družba 1988.

${ }^{44}$ Navedeno po Klemenčič 1999 (1), 271.

${ }^{45} \mathrm{Ib}$.
} 
nosti, in če to napravijo vsi - in to je edina naloga - čemu vsa skrb, da se ustvari nacionalno karakteristična muzika?" ${ }^{46}$ Gre torej za še danes veljavno stališče: če je skladatelj zrasel s svojim narodom, če je v njem zakoreninjen, in če se je polno izrazil, ne more, da ne bi izrazil duha svojega naroda. In če je bil kot človek velik in prepričljiv, ne more, da ne bi izrazil veličine svoje občečloveškosti. Glede na to terja Vurnikovo stališče dopolnitev: glasbena umetnost preseže nacionalne okvire takrat, ko je za mednarodno skupnost relevantna kot nacionalna in občečloveška vrednota.

Zato je Osterc sredi tridesetih let afirmativno zapisal po praški izvedbi svojega Koncerta za klavir in pihala: "Češke kritike ugotavljajo pri moji skladbi izredno vitalnost, tehnično in kvalitativno evropsko višino, maksimalne razvojne možnosti in pri tem nacionalno noto. ${ }^{47}$ Zlasti razmerje do ljudske glasbene ustvarjalnosti se je pri modernistični generaciji tridesetih let povsem izostrilo. Tako je Osterc lahko ob Lajovčevih zborih ugotavljal, da so "pristno slovenski", "ker komponist ni padel v folkloro, ampak je črpal glasbene domisleke iz sebe, iz svoje notranjosti, in ker je Slovenec, ni mogoče, da bi komponiral v kakem drugem tonu kakor v pristno slovenskem. ${ }^{48} \mathrm{~S}$ tem je zavrnil agresivno folklorno ideologijo iz juga takratne skupne države, kot jo je v polemiki zagovarjal hrvaški skladatelj Antun Dobronić, po katerem Lajovic in Adamič "v nekaterih delih kažeta prizadevanje za vsaj zunanje slovenstvo," medtem ko Kogoj, Osterc in Škerjanc sprejemajo določene moderne parole in zato "nimajo stika z glasbenim slovenstvom. " ${ }^{49}$ Šlo je torej za razlikovanje med intencionalnostjo, oprijemljivostjo, zunanjostjo citata in neoprijemljivostjo, iracionalnostjo nacionalnega duha. Nakazovala pa se je še nova pot, ki jo je iz Osterčevega kroga predstavil Danilo Švara "kot absolvent Seklesove šole“ iz Frankfurta. V polemičnem odgovoru Zakaj ne pišemo folklore se je med tremi možnostmi, se pravi poleg citatov in pisanja $\mathrm{v}$ duhu ljudske pesmi, odločil za najnovejše stališče, temelječe na uporabi folklorne tematike, po kateri je skladba sodobna, a ni folklorna. ${ }^{50}$ To načelo, ki ni bilo niti v evropski romantični glasbi povsem novo, je v sodobnem duhu razmeroma najraje upoštevala mednarodna in do neke meje poznejša slovenska kompozicijska praksa.

Nasilno so ta prizadevanja ustvariti nacionalno identično glasbo prekinili zunanji dogodki, vojna s komunistično revolucijo in nova država totalitarne identitete. Boljševiška Jugoslavija je tako nastala kot umetna ideološka tvorba brez konsenza pripadnikov posameznih narodov glede demokratične in federalne ureditve. Od 1945 je še bolj nasilno združevala civilizacijska in kulturna nasprotja na stiku pravoslavja, islama in katolicizma in z njimi srbsko dominacijo z neokolonialističnimi in prikritimi velikosrbskimi prizadevanji, se pravi državno obliko institucionaliziranega nasilja, ki jo je $\mathrm{v}$ devetdesetih letih 20 . stoletja razbil velikosrbski imperializem. $\mathrm{Na}$ individualni ravni se je posameznika politično in ekonomsko desubjektiviziralo, se pravi reduci-

\footnotetext{
${ }^{46} \mathrm{Ib}$.

${ }^{47}$ Op. cit., 275.

${ }^{48} \mathrm{Ib}$.

${ }^{49} \mathrm{Ib}$.

${ }^{50} \mathrm{Ib}$.
} 
ralo v objekt politike, s čimer je bil z resnico in svobodo zavržen tudi ogromen narodov ustvarjalni potencial. Slovenski narod je tako za domala pol stoletja izstopil iz svoje zgodovine in s tem iz zahodne demokratične civilizacije. Preobrat so po padcu berlinskega zidu izsilile nove demokratične sile, ki so sprejele osamosvojitveni akt slovenskega parlamenta 25. junija 1991, in po desetdnevni vojni s prosrbsko in srbizirano Jugoslovansko armado z vojaško zmago obranile slovensko ozemlje in samostojnost. ${ }^{51}$ Boj za demokratizacijo Slovenije zaradi razmerja sil še ni končan, demokratična javnost si vsekakor prizadeva za vrednostno in fizično vrnitev slovenskega naroda $\mathrm{v}$ zahodnoevropsko demokracijo in civilizacijo in za narodno spravo. ${ }^{52}$

Glede na to označuje povojno obdobje na eni strani prizadevanje, da si slovenski človek dopolni, razvije ali na novo oblikuje vse kulturne ustanove, ki jih rabi za polno duhovno življenje naroda, tudi glasbene, in na drugi strani njihova neavtonomnost in ideologiziranost. To je pomenilo vsebinski in z njim kadrovski nadzor, cenzuro in samocenzuro, stvarneje repertoarno deformacijo poustvarjalnih ustanov in seveda finančno omejenost, ki ni bila $\mathrm{v}$ skladu $\mathrm{z}$ družbenim brutoproduktom; socialistična republika Slovenija namreč ni bila avtonomna subjektiviteta, da bi smela razpolagati s svojim nacionalnim dohodkom, ki je bil namenjen delovanju drage totalitarne države in je tudi sicer nesorazmerno odtekal na Balkan. Vendarle ta socialistična realnost ni mogla onemogočiti temeljne delavoljnosti in ambicij tudi na glasbenem področju. ${ }^{53}$ Preoblikovani najvišji vzgojni ustanovi se je pridružilo takoj po vojni delo ljubljanske Opere z mednarodnimi uspehi, obnovljenemu radijskemu orkestru (1955) se je pridružila Slovenska filharmonija (1948), danes nosilka 300-letne tradicije in mednarodno priznana ustanova, delovati so začeli mednarodno uveljavljeni komorni ansambli, zbori in solisti, širila se je dejavnost blizu trideset glasbenih festivalov, izdajateljska dejavnost itd. Nacionalni pomen osrednjih poustvarjalnih ustanov in najboljših posameznikov je praviloma dosegal evropsko in lahko svetovno raven, ki ji ni bila neznana vrhunskost. ${ }^{54}$

Sprva, zlasti prvo poldrugo desetletje po končani vojni, je bilo najbolj prizadeto ustvarjanje. ${ }^{55}$ Govorimo o diskontinuiteti s predvojnim obdobjem, ki gre v korak $s$ fizično in duhovno izoliranostjo, $z$ odhodom iz Srednje Evrope in iz Evrope na Balkan in v nerazviti tretji svet. Slogovna zmernost in pritajenost začneta reflektirati obdobje predmodernega, revolucionarnega duha, nesvobodo v negativiteti odslikavata zunanje zatrta in notranje zavrta umetnost. Določneje govorimo bodisi o skladateljski notranji upornosti ali neprilaganjanju bodisi o podleganju pritiskom ali prostovoljnem konformizmu, ki podpira propagando o ustvarjanju boljše socialistične družbe.

\footnotetext{
${ }^{51}$ Podpore za osamosvojitev in leto pozneje priznanje države Slovenije ni bilo sprva pri nekaterih večjih evropskih državah in tedanjem vodstvu Združenih držav Amerike, ki niso pravilno identificirale srbskih pretenzij. Vsekakor najpomembnejša je bila v vodstvu Nemčije in še pri avstrijskih krščanskih demokratih in v Vatikanu. Nemčija, danes za Slovenijo prva gospodarska partnerica, je pravilno razumela politično situacijo pred razpadom Jugoslavije in se je takrat za Slovenijo odločilno angažirala.

52 Klemenčič 1996 (1), št. 3, 52-61.

${ }^{53}$ Klemenčič 1999 (2), 51-65.

${ }^{54}$ Prim mdr. Sivec 1981, Klemenčič 1988 (2), Klemenčič 2002.

55 Za splošno predstavitev skladateljev in njihovih del prim. Rijavec 1975, Rijavec 1979, O'Loughlin 2000, za kritično presojo ustvarjanja in ustvarjalcev Klemenčič 2002.
} 
Kompozicijska realnost $v$ tej zmernosti so predvsem tradicija romantike, romantičnega realizma in še dopustnega impresionizma in z njimi lahko vsakršna deklarativnost in slavilnost od naslovov do glasbenih vsebin. Odnos do modernizma v nacistični Nemčiji se zdaj v bistvu izenači $\mathrm{z}$ odnosom v komunistični Jugoslaviji, preganjani izrojeni umetnosti (Entartete Kunst) se pridruži preganjana dekadentna umetnost, kakor jo $\mathrm{v}$ obeh totalitarizmih predstavlja zlasti subjektivizem glasbenega ekspresionizma. Zato se nekateri skladatelji oprimejo objektivizma in optimizma neoklasicizma, ene širših povojnih možnosti tako na evropskem vzhodu kot na zahodu. V letu 1951 ga denimo najdemo zgoščenega v simfoničnih delih Primoža Ramovša, Uroša Kreka in Marijana Lipovška, ki v antologijski Drugi suiti za godala ne more zatajiti ne vzorov Beethovna ne vplivov Prokofjeva, a tudi ne lirizirano občutenega slovenskega izraza kot izvirnega prispevka evropski glasbi. ${ }^{56}$ Drugi, kot denimo Zvonimir Ciglič, ostajajo pri subjektivizmu ekspresije, nekompatibilnosti težkokrvnega izraza in upornosti po nasilju v režimskih zaporih (simfonična koreografska pesnitev Obrežje plesalk, 1952). Izjemna je še pred sredo petdesetih let pri Matiju Bravničarju kompozicijska gradnja s svobodno uporabo dvanajsttonske vrste. Subjektivistična glasba $\mathrm{z}$ močnim disharmoničnim občutjem sveta političnega emigranta Božidarja Kantušerja iz Pariza, Messiaenovega učenca, $v$ petdesetih letih kaže, kako bi se lahko kontinuirano razvijala slovenska glasba po obdobju med obema vojnama.

Po konsolidaciji komunistične oblasti se je začel proces odpiranja in opuščanja dogmatike socialističnega realizma po zgledu Sovjetske zveze. Ob pritisku ustvarjalcev je konec petdesetih let tudi na vzhodu odmevala znotrajpartijska polemika o umetnosti, v kateri je Josip Vidmar v nasprotju z ždanovsko dogmatičnostjo oponenta umetnostnega ideologa očitno dopustno zagovarjal popolno svobodo umetniškega ustvarjanja, njeno nepartijnost. ${ }^{57} \mathrm{Na}$ prehodu v šestdeseta leta že ugotavljamo idejne vplive iz Darmstadta, Pariza, Varšavske jeseni, Zagrebškega glasbenega bienala, pa tudi oživljanje duha obeh slovenskih zgodovinskih avantgard. Nosilec avantgardnega prevrednotenja in povojnega modernizma je bila mlada generacija skupine Pro musica viva ${ }^{58}$ in nekoliko starejši in takrat vodilni modernist Primož Ramovš. Iz nje izšli Ansambel Slavko Osterc je imel zlasti srednjeevropsko pomembno vlogo pri širitvi novo nastajajoče glasbe. V tujini so skupino dopolnjevali Tržačan Pavle Merkù, poleg Kantušerja v Parizu Janez Matičič, sodelavec skupine Pierra Schaefferja za elektronsko glasbo pri pariškem radiu, in eden vodilnih avstralskih skladateljev Božidar Kos. Njeno bistveno razširitev v konici svetovnih avantgardnih in modernističnih prizadevanj pomeni Vinko Globokar, poleg študija $\mathrm{v}$ domovini in Parizu s sedežem delovanja od ZDA do Kölna, Berlina, Pariza in od 1995 znova Berlina Evropejec in svetovljan. ${ }^{59}$ Tudi pri tej tretji avantgardistični generaciji je bil sredstvo prevrednotenja subjektivizem ekspresionizma, ki je v poznih različicah radikaliziral duhovnodisharmonično občutje sveta in s tem abstrakcijo v serialnih tehnikah do totalne orga-

\footnotetext{
${ }^{56}$ O slovenskosti Lipovškovega zborovskega opusa prim. Loparnik 1971.

57 Klemenčič 1999 (2), 60.

58 Barbo 2001.

${ }^{59}$ König 1977.
} 
nizacije, s preseganjem estetike tona na področje šuma, na svobodo aleatorike in nove možnosti elektronske glasbe. Nekaterim ustvarjalcem, kot Ramovšu, ${ }^{60}$ Ivu Petriću, tudi Jakobu Ježu ali danes v domovini vodilnemu Lojzetu Lebiču ${ }^{61}$ je bil bliže svobodnejši kompozicijski način poljske glasbe, drugim, prav tako iz skupine Pro musica viva, kot Alojzu Srebotnjaku, Milanu Stibilju, Igorju Štuhecu je bolj ali manj ustrezala eksaktnost dvanajsttonske sistematike in posebej njene razvitejše serialne izpeljanke.

Šestdeseta leta 20. stoletja začne tako označevati novo razmerje med totalitarno družbo in umetnostjo, ki ga nacionalsocializem več ne pozna. Oblast je ohranila model predmodernistične totalitarne države, kar je pomenilo nasilje nad resnico, hkrati pa dopuščala modernizem in avantgardo. Bila je to nova neiskrenost in obenem premišljena prilagodljivost, da si poskuša za ceno ideološke doslednosti pridobiti doma in v svetu nekaj "demokratične " legitimnosti. ${ }^{62}$ Prav tako je ta novi čas šestdesetih let omogočil starejši generaciji, da bodisi iz notranjega eksila romantične ekspresije ali iz neoklasicizma seže $\mathrm{v}$ zmernejše oblike ekspresionizma $\mathrm{z}$ atonalnostjo ali dodekafonijo, kar je omogočilo oblikovanje novega avtentičnega izraza skladateljem Vilku Ukmarju, Bravničarju, Lipovšku, svobodneje Kreku in še komu.

Opuščena ni bila niti skrb ustvarjanju s slovenstvom identične glasbe. Dilema med opisnim folklore in nacionalno izvirnim, med stališči Schönberga in prakso Bartóka, je bila $\mathrm{v}$ tem času načelno presežena. ${ }^{63}$ Zato je želel ekspresionist Bravničar ustvarjati "glasbo, ki ima vonj po naši zemlji, ki izraža ... značilnosti slovenskega bistva," in drugi simfonik Blaž Arnič kot privrženec romantično realistične tradicije oblikovati "svojstven glasbeni jezik, ki ga je mogoče ustvariti le v stiku z domačo zemljo," in pri tem "oživiti predvsem duha in razpoloženja ter čustvovanje ljudske glasbe, ne da bi se pri tem posluževal ljudskih citatov." ${ }^{64}$ Bartókov način je lahko le sprva in omejeno relevanten, kot pri neoklasicističnem Kreku ali zgodnjem povojnem Bravničarju. Kadar pozneje vendarle prihaja do občasnih ekskurzov v folkloro, je to možno predvsem zaradi opustitve njene mimetičnosti, zato jo denimo lahko Uroš Krek vključi v svoj atonalni in celo dodekafonski kompozicijski stavek kot izrazno dopolnilo, kot stopnjevanje, s katerim po njegovih besedah "vdira topel dah neakademskega navdiha." ${ }^{65} \mathrm{Za}$ avtentičnost nacionalnega izraza se zavzema tudi Lipovšek. Prepričan je, "da to ustvarjanje mora biti naše, ne samo evropsko ali svetovljansko, pa pri tem brezbarvno." Le to nas enakovredno vodi v krog drugih narodov. Ob tem pogoju pa zanj evropska inspirativna bližina ni sporna, začenši z vrednotami "humanizma Srednje Evrope, te čudovite domovine, ki nosi v sebi še vedno komaj načeto bogastvo kulturnih dobrin svojih narodov." ${ }^{66}$

\footnotetext{
${ }^{60}$ Loparnik 1984, Klemenčič 1999 (3), 11-24.

${ }^{61}$ O'Loughlin 1983, 71-81.

${ }^{62}$ Klemenčič 1999 (2), ib.

${ }^{63}$ Prim. Schönberg, Arnold, Folkloristic symphonies (1947), v: Arnold Schönberg, Style and idea, London 1975, in k temu Klemenčič 1999 (1), 268 in 276-278.

${ }^{64}$ Navedeno po Klemenčič 1999 (1), 276.

${ }^{65} \mathrm{~V}$ skladbi Inventiones ferales (1962) za violino in godalni orkester; prim. Klemenčič 2002, 210-211.

${ }^{66}$ Navedeno po Klemenčič 2002, 209.
} 
Za novo generacijo skladateljev iz politično "svinčenih" sedemdesetih let $z$ vsakršno kompozicijsko zmernostjo vsaj pri večini ne bi mogli trditi, da prinaša postmodernistično sintezo modernizma, pri katerem še vztraja starejša generacija. Takšno umirjanje poudarjenega subjektivizma je bližje v naslednjih dveh desetletjih mlajšim ustvarjalcem. $\mathrm{V}$ postmodernistični usmerjenosti devetdesetih let najizrazitejši je Marko Mihevc iz srednje generacije, ki v svojih simfoničnih pesnitvah kot pri preslikavi realistične slike uporablja tehniko nalaganja tonalnih ali atonalnih zvočnih ploskev eno na drugo. Virtuozno obvladanje orkestra in te glasbene oblike mu je po študiju $\mathrm{v}$ Ljubljani in na Dunaju dal neposreden študij opusa Richarda Straussa. Med starejšo generacijo ostaja v svoji modernistični nepopustljivosti najradikalnejši in vsebinsko najpobudnejši Vinko Globokar, ki ga kot družbenokritičnega umetnika vodi načelo etika pred estetiko. Odtod se začenja iz svoje glasbene abstrakcije odpirati tudi zunanjosti, tako v skladbi Eisenberg (praizvedba orkestrske verzije $1994 \mathrm{v}$ Ljubljani), posvečeni kraju njegovih dedov na Dolenjskem, stilizirano in sublimirano zazvenijo lokalna konkretnost fužin, živalskih glasov iz kmetskega okolja, naravnih pojavov, oglašata se godba na pihala, harmonika. Ustvarjanje Ramovša in Lebiča zaznamuje deloma in bolj umirjanje disharmonije in abstrakcije izraza začenši z osemdesetimi leti in $\mathrm{v}$ kakem delu že prestop Rubikona postmodernizma, kar poteka skladno z Lebičevim novejšim načelom, da "je glasbi treba vrniti več pripovedne moči ...." ${ }^{67}$ Pri njem in še kom iz modernistične generacije lahko zasledimo za utemeljevanje slovenskega občutja tudi občasno uporabo drobcev ljudske glasbe ali predvsem ustvarjenih v njenem duhu. Lahko pa se, kot pri Srebotnjaku, rešuje "prepad med skrajno abstrakcijo sodobne glasbe in figurativnostjo folklornega elementa " ${ }^{68}$ po postmodernističnem modelu $\mathrm{z}$ izoliranimi in statičnimi citati, $\mathrm{v}$ tem primeru stare slovenske ljudske pesmi (orkestralna Slovenica, 1976). Nasprotno se je Vinko Globokar izvirno in celo z uporabo ljudskih glasbil iz svetovne zakladnice sem in tja odzival na ljudsko ustvarjalnost bolj s subjektivnim komentiranjem in psihoanalizo svojih spominov. ${ }^{69}$ Mimo teh posebnosti ostaja seveda poglavitno vodilo avtonomnost glasbenega izraza, tudi pozneje in pri ustvarjalcih, ki so se umetniško izvirno dvignili nad povprečje. Tako bolj načelen odmik od radikalnega modernizma $s$ specifično uporabo kompozicijskih sredstev in z njim prepoznavanje slovenskega izraza izpričuje predstavnik srednje generacije Uroš Rojko, ki živi in ustvarja med Freiburgom in rojstno Ljubljano, kjer je profesor na Akademiji za glasbo, in ki ga je pri tem spodbudil po Ljubljani in Freiburgu še študij pri Ligetiju v Hamburgu. Dobitnik uglednih evropskih nagrad potrjuje dejstvo, da slovenska glasba nadaljuje in obnavlja svoja temeljna prizadevanja na nacionalni kakor tudi na evropski in širši ravni.

Točneje in celoviteje glede na povedano govorimo o kontinuiteti razvoja na Slovenskem, ki je kontinuiteta evropskega razvoja, sprememb vrednot in duha časa in $s$

\footnotetext{
${ }^{67}$ Navedeno po Klemenčič 2002, 221. Nastavke novega pri Lebiču denimo izpričuje 1983 Streichquartett, nastal po naročilu Deutscher Verlag für Musik, delno umirjanje najdemo v velikih lokih Queensland music, nastale 1989 po naročilu Australian music Centre za Queenslandski simfonični orkester.

${ }^{68}$ Navedeno po Rijavec 1979, 272.

${ }^{69}$ Klemenčič 1999 (1), 278.
} 
tem razčlenjenosti od srednjega veka, renesanse, reformacije in protireformacije, baroka, razsvetljenstva, klasicizma, romantike, impresionizma, modernizma ekspresionizma in nove stvarnosti, po povojnem zastoju $\mathrm{z}$ ideologizacijo umetnosti obnavljanja neoklasicističnih in ekspresionističnih praks do prodora modernizma $\mathrm{z}$ avantgardizmom in postmodernističnega umirjanja. To slovensko duhovno sobivanje in oplajanje najprej v srednjeevropskem okviru, kar pomeni sprva še neposredno pri slovenskih zahodnih in severnih sosedih, se po svojih močeh ujema s prispevanjem izvirnih dosežkov v skupno evropsko zakladnico. To je izvirnost posameznih skladateljskih osebnosti ali njihovih posameznih del, pomembnost in vrhunskost poustvarjalnih osebnosti in ansamblov, aktualnost nekaterih poustvarjalnih ustanov. Še posebej ustvarjalnost je po marčni revoluciji izpričevala prizadevanja skladateljev utemeljiti slovensko individualnost, identiteto, dragoceno vrednoto kot simbola narodovega obstoja, pa čeprav za znanost neoprijemljive kategorije posebnega izraza in s tem občutja in iracionalnega doživetja. ${ }^{70} \mathrm{~A}$ tudi ta ustvarjalna in $\mathrm{z}$ njo poustvarjalna izvirnost ni bila absolutna, kot že vemo, prej ko slej jo je treba razumeti v plodnem evropskem kontekstu bodisi kot izvirnost $v$ nacionalnem ali/in obenem $v$ evropskem okviru. Slovenska glasba je bila in je tako v nenehnem aktivnem soobstajanju $\mathrm{z}$ evropsko. Od nje je prejemala in njej je po svojih zmožnostih prispevala. Skratka bila je in ostaja njen nedeljivi del.

\section{Bibliography}

Valvasor, Janez Vajkard (1689) Die Ehre des Hertzogthums Crain, Laybach.

Thalnitscher, Janez Gregor (1717) Anales Urbis Labacensis, ms (v Semeniški knjižnici, Ljubljana).

Keesbacher, Friedrich (1862) Die philharmonische Gesellschaft in Laibach seit dem Jahre ihrer Gründung 1702 bis zu ihrer letzten Umgestaltung 1862. Eine geschichtliche Skizze, Laibach.

Radics, Peter von (1877) Frau Musica in Krain, Laibach.

Elze, Theodor (1884) Die slowenischen protestantischen Gesangbücher des XVI. Jahrhunderts, Venedig.

Bock, Emil (1902) Die Philharmonische Gesellschaft in Laibach, 1702-1902, Laibach.

Mantuani, Josip (1905) Jurij pl. Slatkonja, v: Cerkveni glasbenik.

Čerin, Josip (1908) Pesmi slovenskih protestantskih pesmaric, njih viri in poraba $v$ poreformacijskih časih, v: Trubarjev zbornik, Ljubljana.

Slovenski biografski leksikon (1925-1991), 15 zv., Ljubljana.

Mantuani, Josip (1930) Ein Kapitel über die Musikpflege in Laibach zur Zeit Schuberts, v: Studien zur Musikgeschichte, Wien.

Kos, Milko (1936) Conversio Bagoariorum et Carantanorum, Ljubljana.

Ramovš, Fran \& Milko Kos (1936) Brižinski spomeniki, Ljubljana.

\footnotetext{
${ }^{70}$ Prim. k temu še Klemenčič 2002, poglavje O slovenski indentiteti.
} 
Cvetko, Dragotin (1957) Mozarts Einfluss auf die slowenische Tonkunst zur Zeit der Klassik, v: Mozart-Jahrbuch 1956, Salzburg.

Ludvik, Dušan (1957) Nemško gledališče v Ljubljani do l. 1790, Ljubljana.

Cvetko, Dragotin (1958) J. B. Novak - ein slowenischer Anhänger Mozarts, v: Bericht über den internationalen musikwissenschaftlichen Kongress Wien, Graz-Köln.

Cvetko, Dragotin (1958-1960) Zgodovina glasbene umetnosti na Slovenskem (Résumé: Histoire de la musique en Slovénie), I-III, Ljubljana.

Škerjanc, Lucijan Marija (1958) Anton Lajovic. Ob skladateljevi osemdesetletnici, Ljubljana.

Cvetko, Dragotin (1959) Ein unbekanntes Inventarium librorum musicalium aus dem Jahre 1620, v: Bericht über den siebenten musikwissenschaftlichen Kongress 1958, Kassel.

Cvetko, Dragotin (1962) Academia Philharmonicorum Labacensis (tudi Résumé), Ljubljana.

Škerjanc, Lucijan Marija (1963) Kompozicijska tehnika Jakoba Petelina Gallusa (Zusammensfassung), Ljubljana.

Cvetko, Dragotin (1965) Jacobus Gallus Carniolus (tudi Résumé), Ljubljana.

Muzikološki zbornik(1965-), ur. D. Cvetko, A. Rijavec (od 1981) in M. Barbo (od 1998), Ljubljana.

Höfler, Janez (1965) Starejša gregorijanika v ljubljanskih knjižnicah in arhivih, v: Kronika, Ljubljana.

Cvetko, Dragotin (1967) Histoire de la musique slovène, Maribor.

Höfler, Janez \& Ivan Klemenčič (1967) Glasbeni rokopisi in tiski na Slovenskem do leta 1800. Katalog / Music manuscripts and printed music in Slovenia before 1800. Catalogue, Ljubljana.

Rijavec, Andrej (1967) Glasbeno delo na Slovenskem v obdobju protestantizma (Summary: Music in Slovenia in the Protestant Era), Ljubljana.

Cvetko, Dragotin (1969) Gustav Mahlers Saison 1881/82 in Laibach (Slowenien), v: Musik des Ostens.

Loparnik, Borut (1971) O nacionalnem v Lipovškovih zborih, v: Sodobnost, št. 2, Ljubljana.

Sivec, Jože (1971) Opera $v$ Stanovskem gledališču $v$ Ljubljani od leta 1790 do 1861 (Zusammenfassung: Die Oper in Ständischen Theater zu Ljubljana von 1790 bis 1861), Ljubljana.

Cvetko, Dragotin (1972) Jacobus Gallus. Sein Leben und Werk, München.

Sivec, Jože (1972) Kompozicijski stavek Wolfganga Stricciusa (Zusammenfassung: Der Kompositionssatz von Wofgang Striccius), Ljubljana.

Kuret, Primož (1973) Glasbeni instrumenti na srednjeveških freskah (Zusammenfassung: Musikinstrumente auf den mittelalterlichen Fresken Slnweniens), Ljubljana.

Škerlj, Stanko (1973) Italijansko gledališče v Ljubljani v preteklih stoletjih (Riassunto: Il teatro italiano a Ljubljana nei secoli passati), Ljubljana.

Cvetko, Dragotin (1975) Musikgeschichte der Südslawen, Kassel, Maribor (Južni Slovani $v$ zgodovini evropske glasbe, Maribor 1981).

Rijavec, Andrej (1975) Twentieth Century Slovene Composers / Slowenische Komponisten des 20. Jahrhunderts, Ljubljana, Köln. 
MUZIKOLOŠKI ZBORNIK • MUSICOLOGICAL ANNUAL XXXIX

Cvetko, Dragotin (1977) Vloga Gojmira Kreka v razvoju novejše slovenske glasbe (Zusammenfassung: Die Rolle G. Kreks in der Entwicklung der neueren slowenischen Musik), Ljubljana.

König, Wolfgang (1977) Vinko Globokar. Komposition und Improvisation, Wiesbaden.

Höfler, Janez (1978) Glasbena umetnost pozne renesanse in baroka na Slovenskem, Ljubljana.

Sivec, Jože (1978) Die Oper zu Ljubljana (Laibach) und ihre Beziehungen zu den deutsch-österreichischen Theatergesellschaften in Zeitalter der Klassik, v: Grazer musikwissenschaftliches Arbeiten.

Rijavec, Andrej (1979) Slovenska glasbena dela, Ljubljana.

Bedina, Katarina (1981) List nove glasbe. Osebnost in delo Franca Šturma, Ljubljana.

Sivec, Jože (1981) Dvesto let slovenske opere / Two hundred years of the Slovene opera, (1780-1980), Ljubljana.

Sivec, Jože (1982) Kompozicijski stavek Daniela Lagkhnerja (Zusammenfassung: Der Kompositionssatz von Daniel Lagkhner), Ljubljana.

Slovenska opera $v$ europskem okviru / The Slovene Opera within the European Framework (1982) simpozij (Ljubljana) 20. in 21. X. 1982, ur. D. Cvetko in D. Pokorn, Ljubljana.

Monumenta artis musicae Sloveniae (1983-) ed. D. Cvetko (1983-1993), D. Pokorn (co-ed. 1985-1993, ed. 1994-1995), I. Klemenčič (since 1996), I-(for now XIII, 2002), Ljubljana: I A. Ivančič, Sonate a tre, II D. Lagkhner, Soboles musica,1983, 2. ed. 1995; III D. Ivančič, Simfonije za dve violini in bas / Symphonies for two violins and bass, IV J. K. Dolar, Missa villana, 1984, 2. ed. 1995; V-XVII I. Gallus, Opus musicum, Tomus HIV, 1985-1990; XVIII-XXI I. Gallus, Selectiores quaedam missae, Liber FIV, 1991; XXII J. K. Dolar, Missa sopra la bergamasca, 1992, 2. rev. ed. 1997; XXIII J. K. Dolar, Psalmi / Psalms, 1993, 2. rev. ed. 1997; XXIV G. Prenner, Moteti / Motets, XXV J. K. Dolar, Balletti - Sonate, 1994; XXVI I. Gallus, Harmoniae morales, XXVII I. Gallus, Moralia, 1995; XXVIII I. Gallus, V rokopisu ohranjene skladbe / Compositions preserved in manuscript, XXIX J. K. Dolar, Missa Viennensis, XXX I. Posch, Musicalische Ehrenfreudt (1618), XXXI I. Posch, Musicalische Tafelfreudt (1621), 1996; XXXII W. Striccius, Neue Teutsche Lieder (1588), Der Erste Theil Newer Teutscher Gesänge (1593), XXXIII G. Plavec, Flosculus vernalis (1621), 1997; XXXIV D. Lagkhner, Flores Jessaei (1606), Florum Jessaeorum (1607), XXXV I. Posch, Harmonia concertans (1623), 1998; XXXVI J. F. Zupan, Arije in dueti / Arias and duets, 1999; XXXVII V. Wratny, Missa in B, XXXIX V. Wratny, Missa in A, 2000; XI G. Puliti, Sacri concentus (1614), ungenti dardi spirituali (1618), XII V. Wratny, Missa in G, 2001; XIII G. Puliti, Lilia convalium (1629), Sacri accenti (1620), XLIII L. F. Schwerdt, Missa St. Floriani, 2002.

O'Loughlin, Niall (1983) The Music of Lojze Lebič, v: Muzikološki zbornik.

Loparnik, Borut (1984) Biti skladatelj. Pogovori s Primožem Ramov̌̌em (Summary: To be a composer. Conversations with Primož Ramovš), Ljubljana.

Cvetko, Dragotin (1985) Glasbeni svet Antona Lajovca (Zusammenfassung: Anton Lajovic und seine Musikwelt), Ljubljana. 
Jacobus Gallus and his time / in njegov čas (1985), simpozij 23.-25. oktober 1985, ur. D. Cvetko in D. Pokorn, Ljubljana.

Federhofer-Königs, Renate (1985) Zur Überlieferung der Motetten von Georg Prenner, v: Jacobus Gallus and his time / in njegov čas.

Boetticher, Wolfgang (1986) Jacobus Gallus und Orlando di Lasso. Einige Betrachtungen zumProblem des Stilvergleichs in Motettenrepertoire, v: Muzikološki zbornik.

Klemenčič, Ivan (1986) The historical Avant-garde in Slovene music, v: Soobstoj avantgard / Coexistance among the Avant-gardes, mednarodni kolokvij, Ljubljana.

Enciklopedija Slovenije (1987-2002), 16 zv., Ljubljana.

Globokar, Vinko (1987) Vdih - izdih (Summary: Breathing in - breathing out), Ljubljana.

Snoj, Jurij (1987) Fragmenti srednjeveških koralnih rokopisov s poznogotsko notacijo $v$ Ljubljani, diss., tipkopis, Ljubljana.

Cvetko, Dragotin (1988) Fragment glasbene moderne. Iz pisem Slavku Ostercu (Introduction: A fragment of musical modernism. From letters to Slavko Osterc), Ljubljana.

Evropski glasbeni klasicizem in njegov odmev na Slovenskem / Der europäische Musikklassizismus und sein Widerhall in Slowenien (1988), mednarodni simpozij, Ljubljana 26.-28. 10. 1988, ur. D. Cvetko in D. Pokorn, Ljubljana.

Flotzinger, Rudolf (1988) Der Sonderfall Wiener Klassik-zur Beurteilung ihrer Rezeption in Slowenien, v: Evropski glasbeni klasicizem in njegov odmev na Slovenskem.

Klemenčič, Ivan (1988) Častni člani ljubljanske Filharmonične družbe (Zusammenfassung: Ehrenmitglider der Philharmonischen Gesellschaft von Ljubljana), v: Evropski glasbeni klasicizem in njegov odmev na Slovenskem.

Klemenčič, Ivan (1988) Slovenska filharmonija in njene predhodnice / The Slovene philharmonic and its predecessors, Ljubljana.

Klemenčič, Ivan (1988) Slovenski glasbeni ekspresionizem. Od začetkov do druge vojne (Summary: Slovene musical expressionism. From its beginnings to the Second World War), Ljubljana.

Umetnik in družba. Slovenska glasbena misel po prvi vojni (Lajovic, Kogoj, Vurnik) (1988) [ur. in uvodno razpravo napisal] P. Kuret, Ljubljana.

Faganel, Tomaž (1989) Kompozicijski stavek v mašnem opusu Janeza Krstnika Dolarja, mag. delo, tipkopis, Ljubljana.

Šavli, Jožko (1990) Slovenska država Karantanija. Institutio Sclavenica, Koper, Dunaj, Ljubljana.

Tomažič, Ivan (1990) Novo sporočilo knjige Veneti, naši davni predniki, [avtorji] Matej Bor, Jožko Šavli, Ivan Tomažič, Ljubljana (Unsere Vorfahren die Veneter, Wien 1988; Veneti, First Builders of European Community; Tracing the History and Language of Early Ancestors of Slovenes, Wien, Boswell 1996).

Pokorn, Danilo (1990-1991) Slovenski skladatelj Jakob Zupan (Zusammenfassung: Der slowenische Tonsetzer Jakob Zupan), v: Radovi, Zavod za znanstveni rad HAZU Varaždin. 
Cvetko, Dragotin (1991) Iacobus Hándl Gallus vocatus Carniolanus [angleško besedilo], Ljubljana.

Cvetko, Dragotin (1991) Slovenska glasba v evropskem prostoru (Summary: Slovene Music in its European Setting), Ljubljana.

Gallus Carniolus in europska renesansa / Gallus Carniolus und die europäische Renaissance (1991 in 1992), mednarodni simpozij, Ljubljana 21.-24. 10. 1991, 2 zv., ur. D. Cvetko in D. Pokorn, Ljubljana.

Gallusov zbornik. Prispevki h Gallusovi biografiji (1991), zbral in ur. E. Škulj, Ljubljana.

Gallusovi predgovori in drugi dokumenti (1991), zbral in ur.E. Škulj, Ljubljana.

Škulj, Edo (1992) Gallusov katalog. Seznam Gallusovih skladb, Ljubljana.

Bedina, Katarina (1992) Fenomen glasbenega baroka na Slovenskem (Summary: The Phenomenon of Baroque Music in Slovenia), v: Muzikološki zbornik.

Klemenčič, Ivan (1992) Rod in ljubljanska leta Franca Pollinija (Summary: The Ljubljana Period of Francesco Pollini and His Family Background), v: Muzikološki zbornik (Franc (Francesco) Pollini's Ancestors and His Early Career in Ljubljana, v: Off-Mozart, Zagreb 1995).

Antonio Tarsia, 1643-1722 (1993). 350 let / anni, [ur.] S. Žitko, Koper.

Cvetko, Dragotin (1993) Osebnost Slavka Osterca (Summary: The personality of the composer Slavko Osterc), Ljubljana.

Faganel, Tomaž (1993) Psalmi Janeza Krstnika Dolarja (Zusammenfassung: Die Psalmen des Janez Krstnik (Ioanes Baptista) Dolar), v: Muzikološke razprave.

Faganel, Tomaž (1993) Zu Fragen der Aufführungspraxis in den Werken von Joannes Baptista Dolar, v: Musik des 17. Jahrhunderts und Pavel Vejvanovský, Brno.

Marij Kogoj, 1892-1992 (1993) Zbornik referatov s kolokvija ob stoletnici skladateljevega rojstva 7. 10. $1992 v$ Ljubljani / Proceedings from the colloquium held in Ljubljana at the centenary of the composer's birth on October $7^{\text {th }}$, 1992, ur. I. Klemenčič, Ljubljana.

Muzikološke razprave (1993), ur. D. Pokorn, Ljubljana.

Höfler, Janez (1994) Življenje in delo Antonia Tarsia (Summary: The Life and Work of Antonio Tarsia), v: Muzikološki zbornik.

Faganel, Tomaž (1994) Glasbena zapuščina Antonia Tarsie (Summary: The Musical Bequest of Antonio Tarsia), v: Muzikološki zbornik.

Kokole, Metoda (1995) The Baroque Musical Heritage of Slovenia, v: The Consort, London.

Florjanc, Ivan \& Edo Škulj (1996) Slovenski protestantski napevi, Ljubljana.

Klemenčič, Ivan (1996) O stanju duha na Slovenskem, v: Zaveza, Ljubljana (Slovenec 1996, št. 228 in 234).

Klemenčič, Ivan (1996) Slavko Osterc composing between neoclassicism and expressionism, v: Glasba med obema vojnama in Slavko Osterc / Musik zwischen beiden Weltkriegen und Slavko Osterc. Slovenski glasbeni dnevi 1995, ur. P. Kuret, Ljubljana.

Kokole, Metoda (1996) The Academia Philharmonicorum Labacensium (1701c. 1769), v: Seventh Biennial Conference on Baroque Music, Birmingham. 
Pokorn, Danilo (1996) Baroni Khisli in njihovo mecenstvo (Zusammenfassung: Die Barone Khisl und ihr Mezänatentum). In: Grafenauerjev zbornik, Ljubljana.

Zbornik Brižinski spomeniki (1996), ur. J. Kos, F. Jakopin in J. Faganel, Ljubljana. Klemenčič, Ivan (1997) Musik im Zeitalter des Barock: ihre Stilentwicklung in Slowenien, v: Musicologica Austriaca, Wien.

Snoj, Jurij (1997) Medieval Music Codices. A selection of Representative Samples from Slovene Libraries, Ljubljana (slovenska izdaja prav tako 1997).

Glasbeni barok na Slovenskem in evropska glasba / Baroque music in Slovenia and European music (1997). Zbornik referatov $\mathrm{z}$ mednarodnega simpozija 13.-14. 10. 1994 v Ljubljani, ur. I. Klemenčič, Ljubljana.

Klemenčič, Ivan (1998) The musical Expression of Marij Kogoj, v: Kunst-Gespräche. Musicalische Begegnungen zwischen Ost und West, Hg. Peter Andraschke/Edelgard Spaude, Freiburg im Breisgau.

Klemenčič, Ivan (1998) Slowenien, v: Die Musik in Geschichte und Gegenwart. Zweite, neubearb. Ausg. Sachteil Bd 8, Kassel [etc.].

Srednjeveška glasba na Slovenskem in njene evropske vzporednice / Medieval music in Slovenia and its european connections (1998). Zbornik referatov z mednarodnega simpozija 19. -20. 6. 1997 v Ljubljani, ur. J. Snoj, Ljubljana.

Kuret, Primož (1998) Popotni dnevniki Paola Santonina 1485-1487(Summary: Itineraries of Paolo Santonino 1485-1487), v: Srednjeveška glasba na Slovenskem in njene evropske vzporednice.

Klemenčič, Ivan (1999) Ljudska glasba znotraj umetne (Summary: Folk Music Within Art Music), v: Jubilejni zbornik ob 75-letnici dr. Zmage Kumer, Ljubljana.

Klemenčič, Ivan (1999) Music and the Totalitarian State in Slovenia, v: Glasba in družba v 20. stoletju, Slovenski glasbeni dnevi 1998, ur. P. Kuret, Ljubljana.

Klemenčič, Ivan (1999) Zvočni svet Primoža Ramovša (1921-1999) (Summary: The Sonorous World of Primož Ramovš), v: Muzikološki zbornik.

Kokole, Metoda (1999) Isaac Posch, "diditus Eois Hesperiisque plagis - slavljen v deželah Zore in Zatona". Zgodnjebaročni skladatelj na Koroškem in Kranjskem, Ljubljana.

Škrjanc, Radovan (1999) Vprašanje sloga v skladbah Jakoba Frančiška Zupana, mag. delo, tipkopis, Ljubljana.

Gallus, Jacobus, Moralia - Harmoniae morales (2000), [ansambel] Singer Pur [Regensburg], [tri zgoščenke s knjigo], ur. T. Faganel, Ljubljana, Freiburg.

O'Loughlin, Niall (2000) Novejša glasba v Sloveniji, osebnosti in razvoj, Ljubljana.

Škulj, Edo (2000) Clare vir. Ob 450-letnici rojstva Iacobusa Gallusa (Résumé; Resumen; Riassunto; Summary; Zusammenfassung), Ljubljana.

Zbornik ob jubileju Jožeta Sivca / Essays presented to Jože Sivec (2000), ur. J. Snoj in D. Frelih, Ljubljana.

Klemenčič, Ivan (2000) Šesta simfonija Ludwiga van Beethovna in njegove zveze $z$ Ljubljano (Summary: The Sixth Symphony by Ludwig van Beethoven and His Connections with Ljubljana), v: Zbornik ob jubileju Jožeta Sivca.

Barbo, Matjaž (2001) Pro musica viva. Prispevek k slovenski moderni po II. svetouni vojni (Summary: Pro musica viva. A post Second World War contribution to Slovenian Modernism), Ljubljana. 
Klemenčič, Ivan (2001) Slovenia, Art music, v: The New Grove Dictionary of Music and Musicians, 2nd ed., vol. 23, London, New York.

Kuret, Primož (2001) Mahler in Laibach. Ljubljana 1881-1882, Wien, Köln, Weimar, Böhlau (Wiener Schriften zur Stilkunde und Aufführungspraxis; Sonderband 3).

Slovenska filharmonija-Academia philharmonicorum, 1701-2001(2001), Ljubljana. Klemenčič, Ivan (2002) Musica noster amor. Musical Art of Slovenia from its Beginnings to the Present. An Anthology on 16 CDs with an Accompanying Book, Maribor, Ljubljana (slovenska izdaja 2000). 